https://doi.org/10.48009/2_iis_2010_184-190

\title{
COLLEGE FRESHMEN SELF-ASSESSMENT OF CORE ACADEMIC BEHAVIORS: IMPLICATIONS FOR INFORMATION SYSTEMS FACULTY
}

\author{
Melody W. Alexander, Ball State University, malexander@bsu.edu \\ Sherry A. Woosley, Ball State University, swoosley@bsu.edu \\ Allen D. Truell, Ball State University, atruell@bsu.edu \\ Jensen J. Zhao, Ball State University, jzhao@bsu.edu
}

\begin{abstract}
All entering freshman at the researchers' university are encouraged to complete the MAP-Works ${ }^{\circledR}$ (Making Achievement Possible) survey during the third week of the first semester. Out of the 3,583 freshmen who completed the survey, 436 were prebusiness majors. One of the core course requirements for all pre-business freshmen is an introductory information systems class. The purpose of this study was to examine pre-business students' self- assessment of core academic behaviors in firstsemester classes. A secondary purpose was to identify any differences in self-assessment of core academic behaviors between males and females. Results of the study revealed that freshmen students self-assessment of core academic behaviors differ between genders. Implications and areas of further research for information systems faculty are suggested.
\end{abstract}

Keywords: Academic Behavior, College Freshmen, Information Systems Faculty, Gender, SelfAssessment

\section{INTRODUCTION}

Beginning college freshmen face many transitions during the first semester of college. Many adjustments must be made to succeed in the college environment $[7,19]$. Students, who are not able to make these adjustments, may possibly drop out [8].

As a result of drop out rates, student retention and academic performance is a top priority at institutions of higher learning $[10,13]$. According to Giaquinto [11] one of the most important issues that needs to be addressed in student retention, is in the instruction received in first-semester classes. As compared with non-returning students, students who returned for their sophomore year reported putting forth more of an effort to obtain good grades [10].

A study on college students by Bai and Pan [2] found that various forms of interaction improved male and female retention rates. Numerous colleges and universities are administering surveys to beginning freshmen to identify areas of needed intervention [5]. The benefits of self-assessment surveys for both students and faculty have been documented by several researchers $[17,18,21]$.

\section{MAP-Works® Survey}

MAP-Works ${ }^{\circledR}$ is a registered survey designed to gather information from freshmen and sophomore students and is used for student retention and academic success [14]. In the 2009 fall term, 74 institutions participated in the MAP-Works ${ }^{\circledR}$ firstyear survey [16]. The MAP-Works survey is initially administered to first-semester freshmen during the third week of class, and can therefore be used to identify students who may be at risk early in the semester [14].

The intention of MAP-Works ${ }^{\circledR}$ is to help faculty and staff minimize the number of students who will drop out, by uncovering issues that can be flagged and addressed [9]. Universities such as Ball State, Casper College, Hastings College, Iowa State, Slippery Rock, and the University of Illinois who use MAPWorks ${ }^{\circledR}$ have reported impressive student retention rates $[3,1,4,12,15,20]$.

As retention rates continue to be an important issue at colleges and universities, utilizing previously gathered data to address course specific goals is of value. The variable of gender was selected for further analysis as it was found that male tend to have lower GPA's and are likely to receive more academic warnings as compared to females [6]. This study, therefore, analyzes core academic behaviors and provides information systems faculty with a gender comparison.

\section{PURPOSE}

One of the core course requirements for all prebusiness freshmen is an introductory information systems class. The purpose of this study was to examine pre-business students' self- assessment of core academic behaviors in first-semester classes. A 
secondary purpose was to identify any differences in self-assessment of core academic behaviors between males and females.

To address this purpose, answers to the following research questions were investigated:

1. What are pre-business college freshmen selfassessments of core academic behaviors in firstsemester courses?

2. What are pre-business freshmen male and female self-assessments of core academic behaviors in first-semester courses?

3. Are there statistically significant differences between pre-business freshmen male and female self-assessments of core academic behaviors in first-semester courses?

Compilation of these results will provide valuable data for faculty involved with first-semester introductory information systems courses. As a main goal of any program is retention, this information will also be important for information systems course administrators and chairs as they will be provided with a clearer picture of the students' evaluation of their academic behaviors after the first three weeks of classes. Furthermore, recognizing differences in gender will assist information systems faculty in making timely interventions or adjustments as appropriate to address both male and female student course behaviors.

\section{PROCEDURES}

The procedures used to conduct the study are outlined in the following section and include a description of the study participants, instrument, data collection, data analysis, and gender data.

\section{Participants}

The participants for this study were pre-business college freshmen enrolled in their first semester courses during the fall 2009 semester. The survey was offered during the third week of classes by the Office of Academic Assessment and Institutional Research at a mid-sized, Midwestern university. All 485 pre-business freshmen were contacted during the third week of classes.

\section{Instrument}

The Making Achievement Possible (MAP-Works ${ }^{\circledR}$ ) survey was designed to identify students' strengths and areas of needed improvement for college success. The MAP-Works ${ }^{\circledR}$ survey included six items relating to core academic behaviors: attendance, participation, note-taking, turning in assignments, organization (recording) of assignments and tests, and study time. Student participants reported their assessment of each academic behavior using a seven-point Likert type scale. Rating options ranged from 1 (not at all) to 7 (always).

\section{Data Collection}

All entering freshmen students were emailed a request to participate in the MAP-Works ${ }^{\circledR}$ survey during the third week of the fall 2009 semester. A total of 3,947 freshmen were enrolled, and 485 of the freshmen were admitted as pre-business majors. Residence hall directors and staff remind and encourage freshmen to fill out the survey and two email reminders to non-respondents were sent. Of the 485 pre-business majors, 436 participated in the MAP-Works ${ }^{\circledR}$ survey. There were 418 useable responses, which resulted in an $86 \%$ response rate.

\section{Data Analysis}

The data for this study was collected as an institutional initiative. The analysis for this study was performed using data from these existing records. The research was conducted in accordance with the university's Institutional Review Board (IRB) guidelines. All statistical analysis was conducted by the Office of Academic Assessment and Institutional Research. Descriptive statistics provided a gender percentage of the entering freshmen students in the fall of 2009. Frequencies and percentages were calculated to document respondents' assessment of their seven core academic behaviors in beginning courses. Differences by gender and assessment of core academic behaviors were identified by compiling means and standard deviations, then running independent-samples $t$ tests. All tests of significance were determined at the .05 alpha levels.

\section{Gender Data}

There were 418 useable responses from the prebusiness students who completed the MAP-Works ${ }^{\circledR}$ survey. Of this number, $258(62 \%)$ were male and $160(38 \%)$ were female.

\section{FINDINGS}

\section{Research Question One}


Research question one was asked to document prebusiness college freshmen self- assessments of core academic behaviors in first-semester courses. Approximately sixty percent of the respondents reported that during their first three weeks they always attended class (67\%) and turned in assignments on time (55\%). Around thirty percent reported they always pay attention $(28 \%)$, take notes $(27 \%)$, and record assignment and test due dates $(31 \%)$. Less than 20 percent indicated they always spend sufficient time studying (17\%). These findings are shown in Table 1.

Table 1. Pre-Business Freshmen's Assessment of Core Academic Behavior in First-Semester Courses

\begin{tabular}{|c|c|c|c|c|c|c|c|c|c|c|c|c|c|c|}
\hline \multirow{2}{*}{$\begin{array}{l}\text { Core Academic } \\
\text { Behavior } \\
\text { To What Degree } \\
\text { Do You: }\end{array}$} & \multicolumn{2}{|c|}{$\begin{array}{c}1 \\
\text { Never }\end{array}$} & \multicolumn{2}{|c|}{2} & \multicolumn{2}{|c|}{3} & \multicolumn{2}{|c|}{$\begin{array}{c}4 \\
\text { Half of the } \\
\text { Time }\end{array}$} & \multicolumn{2}{|c|}{5} & \multicolumn{2}{|c|}{6} & \multicolumn{2}{|c|}{$\begin{array}{c}7 \\
\text { Always }\end{array}$} \\
\hline & $\#$ & $\%$ & $\#$ & $\%$ & $\#$ & $\%$ & $\#$ & $\%$ & \# & $\%$ & $\#$ & $\%$ & $\#$ & $\%$ \\
\hline Attend class & 2 & 0.5 & 2 & 0.5 & 0 & 0.0 & 20 & 4.8 & 18 & 4.3 & 97 & 23.2 & 279 & 66.7 \\
\hline Pay attention & 2 & 0.5 & 2 & 0.5 & 0 & 0.0 & 34 & 8.1 & 72 & 17.3 & 191 & 45.8 & 116 & 27.8 \\
\hline Take notes & 4 & 1.0 & 1 & 0.2 & 10 & 2.4 & 41 & 9.8 & 66 & 15.8 & 184 & 44.0 & 112 & 26.8 \\
\hline $\begin{array}{l}\text { Turn in assignments } \\
\text { on time }\end{array}$ & 3 & 0.7 & 0 & 0.0 & 2 & 0.5 & 26 & 6.2 & 30 & 7.2 & 127 & 30.5 & 229 & 54.9 \\
\hline $\begin{array}{l}\text { Record assignment } \\
\text { and test due dates }\end{array}$ & 20 & 4.8 & 16 & 3.8 & 21 & 5.1 & 73 & 17.5 & 56 & 13.4 & 102 & 24.5 & 129 & 30.9 \\
\hline $\begin{array}{l}\text { Spend sufficient } \\
\text { time studying }\end{array}$ & 3 & 0.7 & 8 & 1.9 & 17 & 4.1 & 75 & 18.0 & 95 & 22.7 & 151 & 36.1 & 69 & 16.5 \\
\hline
\end{tabular}

\section{Research Question Two}

Research question two was asked to document prebusiness male and female self-assessments of their core academic behaviors in first-semester courses.

Pre-Business Males. After the first three weeks of classes, approximately sixty percent of males reported they always attended class $(63 \%)$, and less than half reported that they always turn in assignments on time (47\%). Over twenty percent of the freshmen males reported that they always paid attention $(26 \%)$, and took notes $(21 \%)$. Less than twenty percent of the males reported that they always recorded assignment and test due dates (19\%), and spent a sufficient amount of time studying (13\%).

Pre-Business Females. After the first three weeks, approximately seventy percent of the females reported they always attended class $(73 \%)$ and turned in assignments on time $(67 \%)$. Half of the females indicated they always recorded assignment and test due dates $(50 \%)$, and over thirty percent always took notes $(37 \%)$ and paid attention (31\%). About twenty percent of the females reported they always spent a sufficient amount of time studying (22\%). These findings are illustrated in Table 2. 
Table 2. Pre-Business Male and Female Freshmen's Assessment of Core Academic Behaviors in First-Semester Courses

\begin{tabular}{|c|c|c|c|c|c|c|c|c|c|c|c|c|c|c|}
\hline \multirow{2}{*}{$\begin{array}{l}\text { Core Academic } \\
\text { Behavior } \\
\text { To What Degree } \\
\text { Do You: }\end{array}$} & \multicolumn{2}{|c|}{$\begin{array}{c}1 \\
\text { Never }\end{array}$} & \multicolumn{2}{|c|}{2} & \multicolumn{2}{|c|}{3} & \multicolumn{2}{|c|}{$\begin{array}{c}4 \\
\text { Half of the } \\
\text { Time }\end{array}$} & \multicolumn{2}{|c|}{5} & \multicolumn{2}{|c|}{6} & \multicolumn{2}{|c|}{$\begin{array}{c}7 \\
\text { Always }\end{array}$} \\
\hline & $\#$ & $\%$ & \# & $\%$ & $\#$ & $\%$ & $\#$ & $\%$ & \# & $\%$ & \# & $\%$ & \# & $\%$ \\
\hline \multicolumn{15}{|l|}{ Attend class } \\
\hline Males & 1 & 0.4 & 2 & 0.8 & 0 & 0.0 & 19 & 7.4 & 16 & 6.2 & 57 & 22.1 & 163 & 63.2 \\
\hline Females & 1 & 0.6 & 0 & 0.0 & 0 & 0.0 & 1 & 0.6 & 2 & 1.3 & 40 & 25.0 & 116 & 72.5 \\
\hline \multicolumn{15}{|l|}{ Pay attention } \\
\hline Males & 1 & 0.4 & 2 & 0.8 & 0 & 0.0 & 29 & 11.3 & 45 & 17.5 & 114 & 44.4 & 66 & 25.7 \\
\hline Females & 1 & 0.6 & 0 & 0.0 & 0 & 0.0 & 5 & 3.1 & 27 & 16.9 & 77 & 48.1 & 50 & 31.3 \\
\hline \multicolumn{15}{|l|}{ Take notes } \\
\hline Males & 3 & 1.2 & 1 & 0.4 & 9 & 3.5 & 36 & 13.9 & 47 & 18.1 & 109 & 42.1 & 54 & 20.8 \\
\hline Females & 1 & 0.6 & 0 & 0.0 & 1 & 0.6 & 5 & 3.1 & 19 & 11.9 & 75 & 47.2 & 58 & 36.5 \\
\hline \multicolumn{15}{|c|}{$\begin{array}{l}\text { Turn in assignments on } \\
\text { time }\end{array}$} \\
\hline Males & 2 & 0.8 & 0 & 0.0 & 2 & 0.8 & 24 & 9.3 & 26 & 10.1 & 82 & 31.8 & 122 & 47.3 \\
\hline Females & 1 & 0.6 & 0 & 0.0 & 0 & 0.0 & 2 & 1.3 & 4 & 2.5 & 45 & 28.3 & 107 & 67.3 \\
\hline \multicolumn{15}{|c|}{$\begin{array}{l}\text { Record assignment and } \\
\text { test due dates }\end{array}$} \\
\hline Males & 16 & 6.2 & 12 & 4.7 & 18 & 7.0 & 63 & 24.4 & 42 & 16.3 & 57 & 22.1 & 50 & 19.4 \\
\hline Females & 4 & 2.5 & 4 & 2.5 & 3 & 1.9 & 10 & 6.3 & 14 & 8.8 & 45 & 28.3 & 79 & 49.7 \\
\hline \multicolumn{15}{|c|}{$\begin{array}{l}\text { Spend sufficient time } \\
\text { studying }\end{array}$} \\
\hline Males & 2 & 0.8 & 4 & 1.6 & 12 & 4.7 & 58 & 22.5 & 58 & 22.5 & 90 & 34.9 & 34 & 13.2 \\
\hline Females & 1 & 0.6 & 4 & 2.5 & 5 & 3.1 & 17 & 10.6 & 37 & 23.1 & 61 & 38.1 & 35 & 21.9 \\
\hline
\end{tabular}

\section{Research Question Three}

Research question three sought to identify significant differences between pre-business male and female freshmen self-assessments of core academic behaviors in first-semester courses. To test for differences between genders, independent-samples $t$ tests were run. Within the category of core academic behaviors, all six items were found to be significantly different between males and females.
In regard to their course behaviors, pre-business female freshman participants reported they attended, paid attention, took notes, turned in assignments on time, recorded assignment and test due dates, and spent a sufficient amount of time studying significantly more as compared with pre-business freshmen male participants. This analysis is displayed in Table 3. 
Table 3. Differences Between Male and Female Freshmen's Assessment of Core Academic Behaviors in FirstSemester Courses

\begin{tabular}{lrrrrr}
\hline Core Academic Behavior & \multicolumn{1}{c}{ Male } & Female & & & \\
To What Degree Do You: & $\boldsymbol{M}^{\mathbf{a}}(\mathbf{S D})$ & $\boldsymbol{M}^{\mathrm{a}}(\mathbf{S D})$ & $\boldsymbol{t}$ & $\boldsymbol{d}$ & $\boldsymbol{p}$ \\
\hline Attend class & $6.37(1.037)$ & $6.67(0.689)$ & -3.513 & 414.023 & $.000^{*}$ \\
Pay attention & $5.81(1.035)$ & $6.05(0.875)$ & -2.585 & 378.480 & $.010^{*}$ \\
Take notes & $5.57(1.197)$ & $6.13(0.901)$ & -5.437 & 398.982 & $.000^{*}$ \\
Turn in assignments on time & $6.12(1.095)$ & $6.59(0.748)$ & -5.170 & 410.585 & $.000^{*}$ \\
Record assignment and test & & & & & \\
due dates & $4.84(1.707)$ & $6.00(1.432)$ & -7.475 & 377.825 & $.000^{*}$ \\
Spend sufficient time studying & $5.22(1.228)$ & $5.55(1.233)$ & -2.688 & 336.261 & $.008^{*}$ \\
\hline
\end{tabular}

${ }^{\mathrm{a}}$ Where $1=$ Never, $4=$ Half of the Time, $7=$ Always

$* \mathrm{p}<.01$.

\section{CONCLUSIONS AND IMPLICATIONS}

This study makes a contribution to the literature as it draws on student self-assessment reports to identify core academic behaviors in first-semester freshmen.

For this study, pre-business college freshmen from a mid-sized, Midwestern university assessed their core academic behaviors in first-semester courses. With these limitations in mind, the following conclusions were drawn.

Research question one documented pre-business freshmen self-assessments of their core academic behaviors in first-semester courses. During the first three weeks of classes, less than seventy percent of the pre-business freshman indicated they always attended class, and less than half indicated they always turned assignments in on time. Around thirty percent indicated they always paid attention, took notes, and recorded assignment and test due dates. Less than twenty percent reported that they always spent sufficient time studying.

As the results of this study imply, many freshmen in introductory information systems courses will struggle with successful core academic behaviors. It would be beneficial for information systems faculty to emphasize and reinforce expected course behaviors at every class meeting during the first three weeks. Organizational suggestions for recording assignment and test due dates could be checked to ensure all students are utilizing a workable method.
Since the majority of these students live in a freshmen dorm, discussing alternate places to study, forming study groups, and scheduling additional study time may be helpful.

Research question two documented freshmen prebusiness male and female self-assessments of core academic behaviors in their first-semester courses. When females and males assessed their core academic behaviors during the first three weeks of class, females reported higher assessments in the "always" rating of attending class, paying attention, taking notes, turning in assignments on time, recording assignment and test due dates, and spending sufficient time studying as compared with males.

The results imply there are differences between male and female students' core academic behaviors. The introductory information systems class is a good course to include group or team work. Information system faculty could utilize this method and form mixed gender groups, which may help to address issues of class attendance and turning in assignments on time.

Research question three identified any differences between pre-business freshmen male and female selfassessments of core academic behaviors in firstsemester courses. All six items within the category of core academic behaviors were found to be significantly different between males and females. 
In all cases, females were more likely to always attend class, pay attention, take notes, turn in assignments on time, record assignment and test due dates, and spend a sufficient amount of time as compared with pre-business freshmen males. All differences were significant. During the first three weeks of class, one would hope the behaviors would not only be higher, but much more consistent between genders. It is important that during the first weeks of classes for information systems faculty to focus on the importance of core academic behaviors and how those behaviors can effect student performance and grades.

Student self-assessment data can be extremely valuable for instructors in supporting freshmen students with their academic learning needs. As supported by Walser [21] these types of selfassessment exercises can be used to foster interactions and relationships with students to help with course success. Both administrators and faculty need to continue to gather and examine information that may influence freshmen students' course behaviors and increase retention rates of freshmen in core classes.

\section{RECOMMENDATIONS FOR FURTHER RESEARCH}

Based on the findings from this study, the following recommendations for additional research are offered.

1. Since this study found that core academic behaviors are assessed higher by females than males, it would be helpful for information systems faculty to examine other areas of the MAP-Works®, including advanced academic behaviors, course studying behaviors, and selfmanagement.

2. As this study focused on student selfassessments of core academic behaviors, further research should compare these findings with students final grades from the introductory information systems course.

3. This study should be replicated in five years. Especially needed is to follow any changes in freshman student assessments of their core academic behaviors and to identify if differences between males and females lessen over time.

\section{REFERENCES}

1. At Iowa State, Participation is Key to Student Success, (2010.) Educational Benchmark (EBI). Retrieved March 12, 2010 from MAP-Works®, Highlights, Campus Highlights: http://www.mapworks.com/Highlights/CampusHighlight_Iowa-State.pdf

2. Bai, H. \& Pan, W., (2009-2010). A multilevel approach to assessing the interaction effects on college student retention. Journal of College Student Retention: Research, Theory \& Practice, 11(2), 287-301.

3. Ball State University Increases Retention 3.9\% Over Three Years, (2010.) Educational Benchmark (EBI). Retrieved March 12, 2010 from MAP-Works ${ }^{\circledR}$ Highlights, Campus Highlights: http://www.mapworks.com/Highlights/Campus-

Highlight_Ball-State.pdf

4. Casper College Students who Participate in MAP-Works® Persist at Higher Rate, (2010). Educational Benchmark (EBI). Retrieved March 12, 2010 from MAPWorks® Highlights, Campus Highlights: http://www.map-works.com/Highlights/ Campus-Highlight_Casper-College.pdf

5. Campus Highlights. (2010). Educational Benchmark (EBI). Retrieved March 5, 2010, from MAP-Works Making Achievement Possible: http://www.mapworks.com/Highlights

6. DeBerard, M. S., \& Julka, D. L. (2000). Correlation of gender with 1st semester GPA and 1st semester academic warning in college freshmen. Unpublished raw data.

7. DeBerard, M. S., Spielmans, G. I., \& Julka, D. L. (2004). Predictors of academic achievement and retention among college freshmen: A longitudinal study. College Student Journal, 38(1) 66-80.

8. Enochs, W. K. \& Roland, C. B. (2006). Social adjustment of college freshmen: the importance of gender and living 
environment. College Student Journal, 40 (1), 63-73.

9. First Year Experience, MAP-Works . (n.d.). Retrieved February 26, 2010, from Wright State University College: http://www.wright.edu/uc/firstyear/experien ce/map-works.htmp

10. Friedman, B. A. \& Mandel, R. G. (20092010). The prediction of college student academic performance and retention: Application of expectancy and goal setting theories. Journal of College Student Retention: Research, Theory \& Practice, 11(2), 227-246.

11. Giaquinto, R. A. (2009-2010). Instructional issues and retention of first-year students. Journal of College Student Retention: Research, Theory \& Practice, 11(2), $267-$ 285.

12. Hastings College increases retention by 4.7\%, (2010). Educational Benchmark (EBI). Retrieved March 12, 2010 from MAP-Works@ Highlights/Campus Highlights: http://www.map-works.com/ Highlights/Campus-Highlight_HastingsCollege.pdf

13. Jones, W. A. \& Braxton, J. M. (2009-2010). Cataloging and comparing institutional efforts to increase student retention rates. Journal of College Student Retention: Research, Theory \& Practice, 11(1), 123139.

14. Overview. (2010). Educational Benchmark (EBI). Retrieved March 5, 2010 from MAPWorks ${ }^{\circledR}$, Overview: http://www.mapworks.com/Overview.aspx

15. Slippery Rock University Increases First-toSecond-Year Retention by 2\%, (2010). Educational Benchmark (EBI). Retrieved
March 12, 2010 from MAP-Works® Highlights, Campus Highlights: http://www.mapworks.com/Highlights/CampusHighlight_Slippery-Rock-University.pdf

16. MAP-Works® Accurately Identifies Students at Risk Throughout the First Term, (February 18, 2010). Educational Benchmarking (EBI). Retrieved March 5, 2010 from MAP-Works®, Research Facts: www.map-works.com/Highlights/ResearchFacts_Check-Up-and-Persistence.pdf

17. Taras, M. (2010). Student self-assessment: processes and consequences. Teaching in Higher Education, v15 (2), 199-209.

18. Tari, J. J. (2010). Self-assessment processes: the importance of follow-up for success. Quality Assurance in Education: An International Perspective, 18(1), 19-33.

19. Toews, M. L.; Yazedian, A. (2007). College adjustment among freshmen: Predictors for white and Hispanic males and females. College Student Journal, 41(4), 891-900.

20. University of Illinois at Chicago College of Business Administration sees Dramatic Rise in Fall-to-Spring Persistence (2010). Educational Benchmark (EBI). Retrieved March 12, 2010 from MAP-Works $®$ Highlights, Campus Highlights: http://www.mapworks.com/Highlights/Campus-Highlight_ UIC-COBA.pdf

21. Walser, T. M. (2009). An action research study of student self-assessment in higher education. Innovative Higher Education, 34 (5), 299-306. 